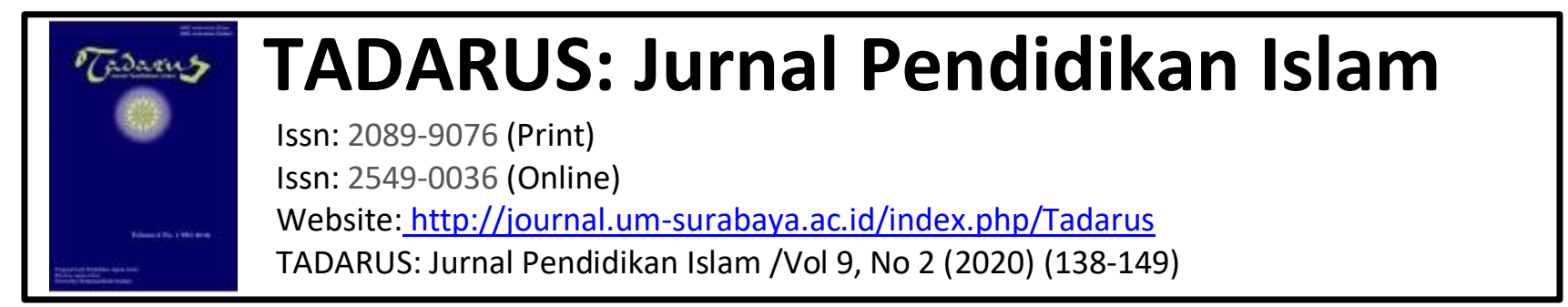

\title{
Modifikasi Kurikulum Sekolah Inklusi Berbasis Aplikasi On-Line
}

\author{
Istikomah $^{1}$, Nurdyansyah ${ }^{2 *}$, Ika Ratna Indra Astutik ${ }^{3}$. \\ ${ }^{1,2}$ Faculty of Islamic Studies, Muhammadiyah Sidoarjo University \\ ${ }^{1,2}$ Faculty of Sains and Technology, Muhammadiyah Sidoarjo University
}

\begin{abstract}
ABSTRAK
Sekolah inklusi adalah sekolah untuk anak berkebutuhan khusus yang diselenggarakan oleh sekolah reguler dengan tujuan untuk memperoleh pendidikan yang layak sebagaimana diamanatkan oleh Undang-Undang Pendidikan No. 20 tahun 2003. Di era baru yang normal ini, guru dituntut untuk dapat melakukan pembelajaran secara online. Dari hasil penelitian ditemukan berbagai permasalahan yaitu dari aspek kurikulum dan tenaga pengajar yang kurang memahami teknis penggunaan TI dalam pembelajaran on-line. Tujuan penelitian ini adalah untuk mendeskripsikan modifikasi kurikulum berbasis aplikasi on-line yang dilakukan oleh guru di sekolah inklusi di Kabupaten Sidoarjo untuk pendidikan dasar. Jenis penelitian ini adalah deskriptif kualitatif dengan sumber data kepala sekolah, guru, pembimbing khusus dan guru kelas. Pengumpulan data dilakukan dengan wawancara, observasi dan dokumentasi. Teknik analisis data melalui tahapan reduksi data, penyajian data dan analisis data. Hasil penelitian menunjukkan bahwa kurikulum sekolah inklusi berbasis aplikasi on-line tidak dapat disamakan dengan sekolah atau kelas reguler, tetapi harus dimodifikasi. Bentuk modifikasi yang telah dilakukan disesuaikan dengan karakteristik dan hambatan siswa yang dikategorikan menjadi tiga jenis yaitu ringan, sedang dan berat. Modifikasi meliputi bahan ajar, bentuk penilaian dan soal pengayaan
\end{abstract}

Kata kunci: modifikasi, kurikulum, sekolah inklusi berbasis aplikasi on-line

\section{Pendahuluan}

Berdasarkan fitroh, semua anak dilahirkan memiliki hak dan kesempatan yang sama untuk mengakses pendidikan yang layak. Sebab peradaban dan kualitas hidup manusia ditentukan oleh pendidikan. Begitu juga dalam Undang-Undang Pendidikan Nasional Nomor 20 tahun 2003 pasal 5 ayat 1 juga telah diamanatkan bahwa semua warga negara berhak untuk memperoleh pendidikan yang bermutu. ${ }^{1}$ Dengan demikian

\footnotetext{
${ }^{1}$ Nurdyansyah, N., \& Fahyuni, E. F. (2016). Inovasi Model Pembelajaran Sesuai Kurikulum 2013. Sidoarjo: Nizamia learning center, 1.
} 
dalam penyelenggaraan pendidikan tidak diperkenankan membedaan antara jenis kelamin, ras, agama atau perbedaan-perbedaan lainya. Namun dalam realitanya manusia yang dilahirkan di muka bumi ini tidak semuanya sempurna, ada yang kurang sempurna atau yang dikenal dengan anak Inklusi/Anak Berkebutuhan Khusus (ABK). Menurut Murtie anak berkebutuhan khusus dibedakan menjadi 2 (dua) karakteristik yang berbeda, pertama, anak dengan karakteristik fisik yang berbeda: tunadaksa, tunanetra, tunarungu. Kedua, anak dengan karakteristik psikis yang berbeda; tunagrahita, learning disability, autis, tunalaras, gifted. ${ }^{2}$

Keragaman anak inklusi tersebut telah memiliki wadah belajar secara khusus di lembaga pendidikan yang dikenal dengan Sekolah Luar Biasa (SLB) ${ }^{3}$. Permasalahanya bagaimana dengan anak-anak yang diluar SLB. Akses pendidikan bagi anak berkebutuhan khusus pemerintah telah menyiapkan satuan pendidikan dengan berbagai corak, pertama, Sekolah Luar Biasa yang diperuntukan untuk siswa dengan berbagai kelainan khusus mulai dari anak usia dini yang berbentuk TamanKanak-Kanak (TK), Sekolah dasar (SD), Sekolah Menengah (SMP) sampai pada tingkat menengah (SMA). Kedua, jenis pendidikan yang terintegrasi dengan sekolah reguler pada umumnya atau disebut dengan sekolah terpadu atau sekolah inklusi. Hal ini diatur oleh pemerintah dalam Peraturan Pemerintah Nomor 17 tahun 2010 pasal 133 tentang “Pengelolaan Penyelenggaraan Pendidikan”

Sekolah inklusi sebagai bentuk pendidikan yang memberikan layanan kepada Anak Berkebutuhan Khusus (ABK) untuk bisa belajar bersama-sama anak normal seusiannya. Menurut Farrel anak dikatakan berkebutuhan khusus jika dia mengalami kesulitan belajar dibandingkan dengan mayoritas anak seusianya ${ }^{4}$. Anak inklusi di Indonesia secara legalitas formal telah memiliki payung hukum yang kuat diantaranya, Undang-Undang Sistem Pendidikan Nasional No 20 Thun 203, Permendiknas No 70 tahun 2009 secara jelas menyatakan bahwa, "pendidikan inklusi sebagai suatu sistem pendidikan yang memberikan akses kesempatan kepada semua peserta didik yang memiliki kelainan teretentu untuk bisa mengikuti pembelajaran dalam suatu lingkungan bersama dengan peserta didik pada umumnya". Adapun tujuannya untuk memberi kesempatan kepada semua peserta didik yang

\footnotetext{
${ }^{2}$ Asrori, Psikologi Pendidikan: Pendekatan Multidisipliner (Purwokerto: Pena Persada, 2020), 80.

${ }^{3}$ Darma, I. P., \& Rusyidi, B. (2015). Pelaksanaan Sekolah Inklusi Di Indonesia. Prosiding Penelitian Dan Pengabdian Kepada Masyarakat, 2(2), 223-227. https://doi.org/10.24198/jppm.v2i2.13530

${ }^{4}$ Farrel, M. (2003). Understanding special educational needs, a guide for student teachers. London: Routledge Falmer
} 
memiliki kelainan dengan berbagai tipe untuk memperoleh pendidikan yang bermutu sesuai dengan kemampuanya ${ }^{5}$.

Penyelenggaraan sekolah inklusi on-line yang dikembangkan ini ingin mengintegrasikan kurikulum yang ada di Indonesia khusus anak inklusi untuk kemudian dikembangkan menjadai berbagai modul dan standar pendidikan berbasis on-line. Sekolah inklusi on-line ini nantinya juga memiliki tutor/pendamping baik bagi orang tua maupun sekolah yang menginginkan ada pendampingan khusus bagi anak inklusi sehingga anak inklusi akan dapat mendapatkan hak pendidikan yang sama dan setara dengan anak normal yang lain.

Layanan sekolah inklusi on-line ini dibuat untuk menjawab hasil survey internasional yang menyatakan bahwa sekolah penyelenggara pendidikan inklusi masih banyak kekurangan guru/ tenaga pengajar dan tutor profesional dengan kompetensi khusus sebagai pendamping anak inklusi. ${ }^{6}$ Sidoarjo merupakan salah satu kabupaten di Jawa Timur yang telah ditunjuk oleh Dinas Pendidikan dan Kebudayaan Propinsi Jawa Timur sebagai sekolah penyelenggra inklusi sehingga dijuluki sebagai kota inklusi. Dengan konsekwensi tiap kecamatan harus ada sekolah inklusi, utamanya sekolah negeri dari tingkat SD-SMP dan SMA.

Dari latar belakang masalah riil yang terjadi diatas maka sekolah inklusi on-line ini menjadi alternatif dan solusi yang tepat pada era new normal ini baik bagi guru maupun orang tua. Saat ini masih ada di Sidaorjo hanya ada 18 kecamatan yang telah menyelenggarakan sekolah inklusi sebagaimana yang telah diamanatkan oleh Dinas Pendidikan propinsi jatim. ${ }^{7}$

Kurikulum yang terlihat berbeda antara sekolah satu dan sekolah yang lain menjadi alasan peneliti untuk membuat modifikasi kurikulum Sekolah Inklusi Berbasis Aplikasi On-Line untuk mempermudah bihak sekolah, pendidik, pesertad idik maupun orang tua. Modul-modul yang dibuat disesuikan dengan rancangan kurikulum yang ada di sekolah khususnya dikabupaten sidoarjo, walupun Secara teori bahwa kurikulum untuk anak sekolah inklusi itu tidak berbeda dengan sekolah reguler

\footnotetext{
${ }^{5}$ Kristiawati, W. dan R. (2016). Gambaran sekolah inklusif di Indonesia: Tinjauan sekolah menengah pertama [The overview of inclusive school in Indonesia: Reviews of Junior High Schools]. Gambaran Sekolah Inklusif Di Indonesia Tinjauan Sekolah Menengah Pertama.

${ }^{6}$ Cooc, N. (2019). Teaching students with special needs: International trends in school capacity and the need for teacher professional development. Teaching and Teacher Education, 83, 27-41. https://doi.org/10.1016/j.tate.2019.03.021

${ }^{7}$ Dinas Pendidikan \&Kebudayaan Kab. Sidoarjo. (2019). Data lembaga Inklusi Se Kabupaten Sidoarjo tahun 2018. Sidoarjo.
} 
pada umumnya. Namun dalam prakteknya kurikulum reguler bagi sekolah inklusi tidak tidak bisa diimplementasikan secara sepenuhnya. Idealnya harus ada kurikulum khusus yang disesuai dengan karakteristik peserta didiknya. Namun dalam realitanya memang belum ada kurikulum khusus untuk sekolah inklusi. Berdasar dari kondisi diatas dengan mempertimbangkan masa pandemi covid 19 ini, maka peneliti membuat Aplikasi Berbasis On-Line khusus untuk anak inklusi yang dinamai dengan Sekolah Inklusion-line.

Untuk itu harus peneliti melakukan bebrapa modifikasi kurikulum sesuai dengan karakteristik individualnya dan hambatan belajarnya. Hal ini merupakan tanggung jawab kita semua untuk berpartisipasi aktif dalam mengembangkan kurikulum berbasis Kebutuhan individu di sekolah inklusi. Sebab jika diberlakukan sebagaimana sekolah pada umumnya tentu tidak akan bisa efektif.

\section{Metode}

Pendekatan penelitian yang relevan digunakan adalah penelitian kualitatif yang menekankan pada pengungkapan makna realitas sosial dari entitas yang diteliti. ${ }^{8}$ Penelitian kualitatif merupakan metode penelitian sosial dimana data yang dihasilkan bukan berupa angka, akan tetapi berupa data deskriptif tentang modifikasi kurikulum sekolah inklusi di kabupaten sidaorjo. Pendekatan penelitian ini mengunakan pendekatan sosial yang berupaya menafsirkan makna dari data sosial yang sifatnya non angka yang akan mendiskripsikan tentang modifikasi kurikulum yang diterapkan di sekolah inklusi yang ada di Kabupaten Sidoarjo. Tujuan penelitian adalah untuk dapat memaparkan secara terperinci tentang modifikasi kurikulum yang yang ada di kancah penelitian.

Dalam penelitian ini peneliti secara langsung berkoordinasi dengan sekolah untuk melihat dan menganalisis silabus dan RPP (Rencana Pelaksanaan pembelajaran), kisi-kisi dan soal evaluasi dan lainya kejadian, peristiwa, perilaku dan sejenisnya yang terkait dengan penyampaikan materi dan bahan ajar. Pengumpulan data dilakukan dengan metode pertama, observasi partisipan dan non partisipan dengan cara terlibat langsung dalam pembelajaran dan melakukan analisa terhadap dokumen kurikulum yang diberlakukan. Kedua wawancara langsung kepada Guru Pendamping Khusus (GPK) Kepala Sekolah, guru kelas maupun guru bidang studi

${ }^{8}$ Lincoln, N. K. D. dan Y. S. (2009). Handbook of Qualitative Research. Terj. Dariyatno dkk. Jogjakarta: Pustaka Pelajar. 
serta kepada wali murid. Ketiga dokumentasi teknik ini digunakan untuk memperoleh data secara menyeluruh tentang obyek penelitian, baik yang terkait dengan gambaran umum obyek penelitian, laporan perkembangan siswa, berbagai catatan harian guru, data guru dan dokumen kurikulum secara menyeluruh rekaman vidio dan berbagai dokumen lain yang diperlukan

Analisa data yang digunakan adalah analisis interaktif yang dikemukakan oleh Miles \& Huberman yang terdiri dati tiga tahapan. Pertama reduksi data yakni kegiatan untuk memfokuskan pada hal-hal yang pokok dalam bentuk merangkum serta memilah dan memilih data yang sesuai untuk dicari pola dan temanya . Kedua, Penyajian data. Kegiatan ini dilakukan dalam bentuk membuat penyajian deskriptifberdasar katagori yang bertujuan untuk memberikan gambaran yang rinci dan jelas. Ketiga, verifikasi atau penarikan kesimpulan. Langkah ini dilakukan untuk menguji kebenaran dan keabsahan data.

\section{Hasil dan Analisa}

Kurikulum merupakan elemen penting dalam pendidikan, sebab didalamnya berisi seperangkat rencana serta pengaturan mengenai bahan dan isi pembelajaran yang dijadikan pedoman dalam aktivitas belajar mengajar. Kurikulum sebagai perangkat pembelajaran yang diberikan oleh suatu lembaga pendidikan kepada peserta didik dalam penyusunanya tentu akan disesuaikan dengan tingkat perkembangan peserta didik dalam setiap jenjang pendidikan. Sebab tujuan utama kurikulum ini adalah untuk memberi arah yang jelas dalam setiap kegiatan pembelajaran untuk semua jenis pendidikan termasuk pendidikan inklusi. Sesuai dengan ketetapan pemerintah kurikulum yang ditetapkan sejak tahun 2013 adalah kurikulum K-13 yang jelas berbeda dengan krikulum sebelumnya yakni KTSP. Penekanan pada kurikulum K-13 adalah kompetensi dan karakter yang dimulai dari pendidikan dasar. ${ }^{9}$

Pendidikan inklusi berbasis aplikasi on-line merupakan suatu bentuk pendidikan yang dirancang dalam rangka untuk mewujudkan konsep pendidikan secara menyeluruh dengan cara menyatukan dan menggabungkan anak inklusi untuk belajar secara tepat, mudah dan efektif. untuk penyelenggaraan sekolah pendidikan inklusi (formal) dalam sistem pendidikan nasional telah diatur dalam Permendiknas Nomor

\footnotetext{
${ }^{9}$ Mulyasa. (2015). Pengembangan dan Implementasi Kurikulum 2013. Bandung: Remaja Rosda Karya.
} 
70 tahun 2009 yang menyatakan bahwa pendidikan inklusi adalah sebagai suatu sistem penyelenggaraan pendidikan yang memberikan kesempatan kepada semua peserta didik yang memiliki potensi kecerdasan atau berbakat dan yang memiliki kelainan untuk mengikuti pendidikan secara bersama-sama dengan peserta didik lainnya. ${ }^{10}$

Berdasarkan definisi pendidikan inklusi sebagaimana di atas, maka pendidikan inklusi berbasis aplikasi on-line ini memiliki tujuan khusus, yakni ingin memberikan kesempatan bagi semua warga negara Indonesia atau peserta didik yang memiliki kelainan atau berkebutuhan khusus, dan juga siswa yang berbakat secara luas untuk bisa mendapatkan kesempatan pendidikan yang berkualitas, serta untuk mengasah potensi diri peserta didik. Teknologi menjadi kunci dalam kesusksesan implementasi sekolah inklusi berbasis aplikasi on-line ini karena menjadi tumpuan utama untuk memfasilitasi anak inklusi mendapatkan fasilitas yang lengkap dan bermutu.

Dalam merancang teknologi untuk pengembangan kurikulum inklusi berbasis aplikasi on-line ini tentunya berdasarkan beberapa hal yang menjadikan pertimbangan diantaranya, pertama setiap anak pada dasarnya nya memiliki bakat minat kemampuan dan latar belakang yang berbeda-beda. Begitu juga bagi anak yang berkebutuhan khusus akan memiliki kondisi yang beragam baik dari aspek mental, emosional, sosial perilaku dan juga aspek fisik. Kedua, dalam tataran psikologi belajar bahwa setiap anak itu akan memiliki gaya belajar dan kemampuan belajar yang sangat berbeda-beda. Ketiga, dalam penyelenggaraan sistem pendidikan saat ini sudah diubah mainsetnya, bahwa yang dimaksud sekolah itu harus mampu mengakomodir kebutuhan semua anak termasuk anak yang berkebutuhan khusus. Untuk itu dalam penelitian ini ingin mengkaji modifikasi kurikulum bagi anak inklusi di Kabupaten Sidoarjo.

Saat ini banyak lembaga pendidikan baik yang negeri maupun swasta telah menyelenggarakan pendidikan inklusi hal ini senada dengan perkembangan jumlah anak yang berkebutuhan khusus di Indonesia dari tahun ke tahun yang terus bertambah. dari data pendidikan dasar menengah Kemendikbud pada tahun 2015 jumlah anak ABK sudah mencapai 1,6 juta namun dari jumlah tersebut hanya 10 sampai $11 \%$ yang bisa mendapatkan layanan pendidikan yang layak. ${ }^{11}$ Kondisi ini

\footnotetext{
${ }^{10}$ Permendiknas No.70 tahun 2009 tentang Sistem Pendidikan Nasioal. (n.d.).

${ }^{11}$ Kristiawati, W. dan R. (2016). Gambaran sekolah inklusif di Indonesia: Tinjauan sekolah menengah pertama (The overview of inclusive school in Indonesia: Reviews of Junior High Schools).
} 
disebabkan oleh berbagai faktor diantaranya orang tua yang kurang mendukung akses sekolah yang yang cukup jauh jaraknya ataupun sekolah belum semuanya siap untuk menerima dan menampung anak berkebutuhan khusus tersebut. Namun sejak sistem zonasi di tetapkan dalam sistem Penerimaan Peserta Didik Baru (PPDB), telah dibuka pendaftaran jalur inklusi dengan pagu masing-masing kelas maksimal 2 siswa dengan persyaratan melampirkan surat keterangan anak berkebutuhan khusus dari dokter/psikolog. Dengan pijakan di atas, pemerintah telah mewajibkan kepada sekolah negeri untuk menerima siswa inklusi dengan beberapa ketentuan tertentu.

Sekolah inklusi di Kabupaten Sidoarjo ini dilakukan secara bertahap yang dimulai pada tahun 2009 yang dilakukan berdasar penunjukan dari Dinas Pendidikan Kabupaten, dan juga ada yang berdasarkan pengajukan dari sekolah sendiri. Sebab regulasi Pemerintah propinsi bahwa masing-masing Kecamatan minimal ada harus ada 3 sekolah inklusi untuk semua jenjang. Subyek dan kancah penelitiaan ini adalah sekolah penyelenggara inklusi di kabupaten Sidoarjo ynag terdiri dari 4 lembaga yakni , 2 SMP, 1 SD dan 1 MI. Data diperoleh dari rumusan masalah yang dikatagorikan dan sudah dikoding dengan hasil analisa data sebagai berikut :

Gambar 1.1

Data Sekolah Inklusi Di Kabupaten Sidoarjo

Tahun Pelajaran 2017/2018 dan 2018/2019

100

0

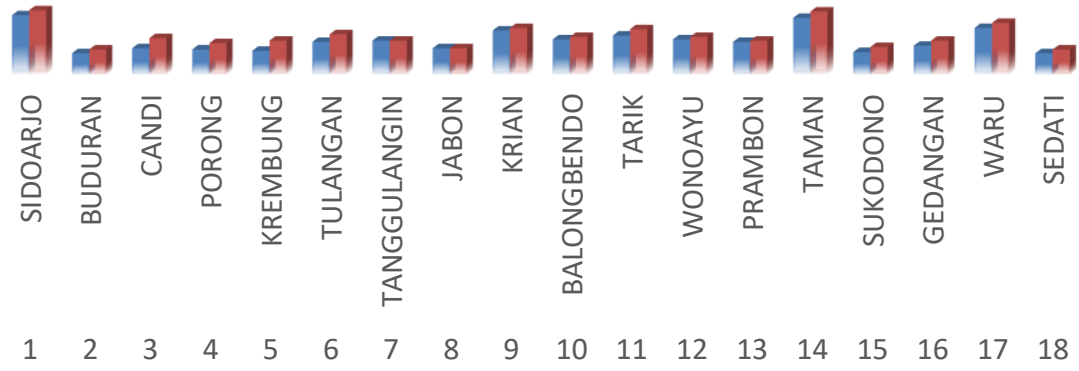

Dari tabel diatas terlihat peningkatan jumlah sekolah inklusi dikabupaten sidaorjo. Namun tidak semua sekolah mampu menampung dan melakukan pembelajaran dengan benar dan sesui standar dikarenakan SDM yang masih belum ada dan alat bantu berupa modul dan alat peraga edukasi yang belum lengkap. Berdasarkan hasil tersebut maka peneliti ingin membantu sekolah untuk anak didiknya yang memiliki keterbatasan mendapatkan kesempatan yang sama. 
Adapun kategori siswa inklusi yang ada dikabupaten sidoarjo berdasarkan hasil observasi, interview dan wawancara lapangan diperoleh data bahwa, peserta didik sekolah inklusi di Sidoarjo sangat beragam. Dalam keberagaman tersebut ada beberapa katagori diantaranya, tuna grahita, tuna daksa, tuna rungu, tuna wicara, autis, ADHD, dan slow learner atau lambat belajar. Dari katagorisasi di atas diatas, yang paling banyak adalah lambat (Slow Learner) sebagaimana dalam diagram dibawah ini.

Gambar 1.2

Karakteristik Siswa inklusi di kabupaten sidoarjo tahun 2018/2019

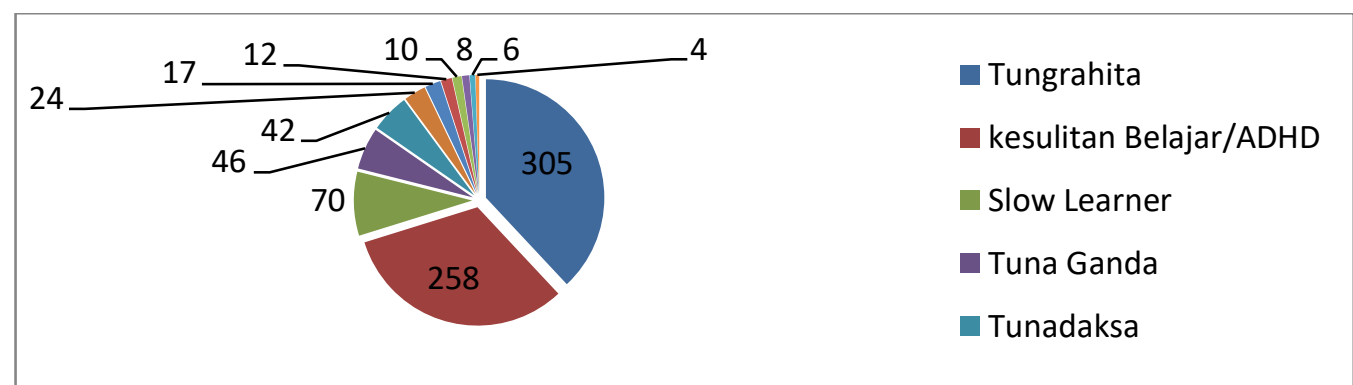

Dari karakteristik sisiwa inklusi di Sidorjo, terutama siswa slow learner atau anak yang mengalami gangguan belajar yang bisa masuk sebagai siswa inklusi harus memiliki IQ dengan skor minimal 71-89. Siswa yang dibawahnya yakni idiot, embecile, debil dan borderline disarankan untuk masuk SLB.

Berdasarkan data diatas dan dari kebijakan dan konsep awal sekolah inklusi, maka dalam proses pendidikanya tidak ada pembedaan di semua aspek. Namun dari sisi tertentu bagi siswa tuna wicara, tuna rungu dan autis dalam hal posisi duduk selaku di taruh di paling depan. Sebab siswa tuna wicara dan tuna rungu hanya bisa memahami pembicraaan guru hanya melalui gerakan bibir, Sedangkan siswa autis memerlukan kendali khusus. Sehingga layanan dan penangganan yang dilakukan oleh pendidik juga harus berbeda.

Modifikasi kurikulum yang akan dilakukan untuk mengatasi berbagai masalah diatas adalah dengan mengintegrasikan berbagai unsur diantaranya kurikulum, materi dan sumber belajar, silabus, RPP, model pembelajaran dan bahan ajar yag akan digunakan sesuai kebutuhan peserta didik. Adapun bagan modifikasi kurikulumnya sebagai berikut: 


\section{Gambar 1.3}

Modifikasi kurikulum Sekolah Inklusi berbasis on-line
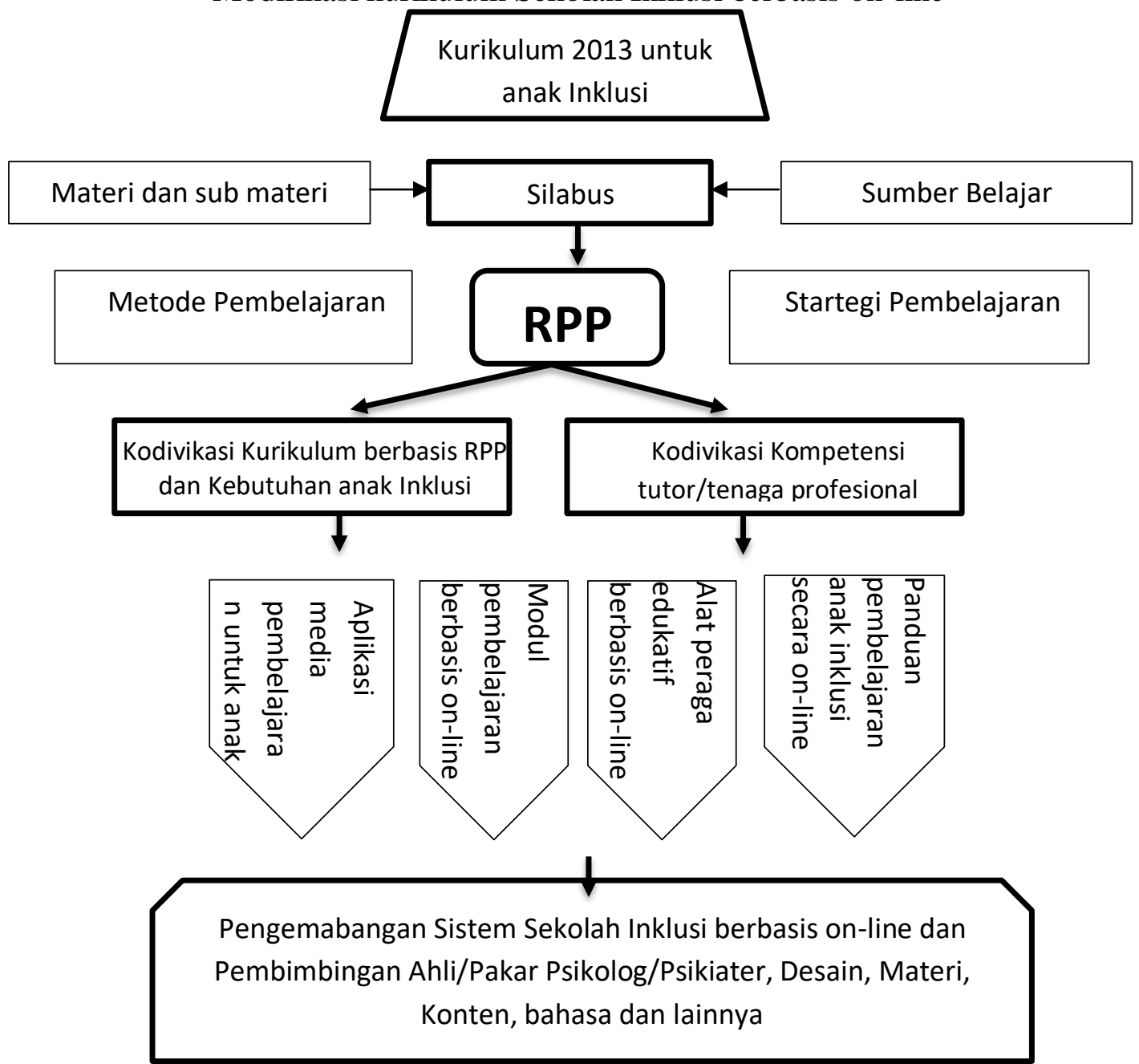

Berdasarkan modivikasi kurikulum diatas, langkah yang dilakukan oleh peneliti antara lain: pertama, peneliti melakukan review kurikulum yang digunakan di sekolah inklusi dan sekolah SLB di Sidoarjo. Kedua, melakukan review silabus yang didasarkan pada materi dan sub materi serta sumber belajar bagi anak inklusi disekolah tersebut. Ketiga, melakukan review RPP yang disesuaikan dengan metode dan strategi pembelajaran dan disesuaikan dengan kebutuhan untuk anak inklusi.

Setelah menganalisis kurikulum rpp dan silabus langkah berikutnya adalah melakukan modivikasi kurikulum berbasis RPP dan Silabus untuk anak inklusi dan selanjutkan melakukan mapping kebutuhan untuk tenaga tutor atau tenaga profesional untuk anak berkebutuhan khusus. ${ }^{12}$ Pada tahap ini perancangan kurikulumnya untuk siswa berkebutuhan khusus atau siswa inklusi dengan melibatkan berbagai pihak

\footnotetext{
${ }^{12}$ Mapunda, P. H.,. (2017). Challenges in identifying and serving students with special needs in Dodoma, Tanzania. International Journal of Child Care and Education Policy, 11(1).
} 
yakni Kepala Sekolah, Guru Pendamping Khusus, guru reguler, psikolog, orang tua, guru kelas dan guru bidang studi.

Modivikasi kurikulum ini dilakukan agar siswa mendapatkan fasilitas dan tambahan belajar secara on-line sesusi dengan kebutuhan dan kondisi siswa. Sejalan dengan apa yang disampaikan oleh Mercer yang menyatakan bahwa "program individualisasi merujuk kepada suatu program pengajaran dimana siswa bekerja dengan tugas-tugas yang sesuai dengan kondisi dan motivasinya". ${ }^{13}$ Dari penjelasan diatas menunjukkan bahwa Modivikasi kurikulum berbasis aplikasi on-line pada prinsipnya adalah suatu program pembelajaran mandiri yang didasarkan kepada kebutuhan individu (anak/siswa) yang dilakukan secara on-line dengan bimbingan tutor dan orang tua. Adapun Prototipe dan aplikasi sekolah Inklusi online yang dirancang sebagai berikut:

Gambar 1.4

Prototipe Sekolah Inklusi on-line

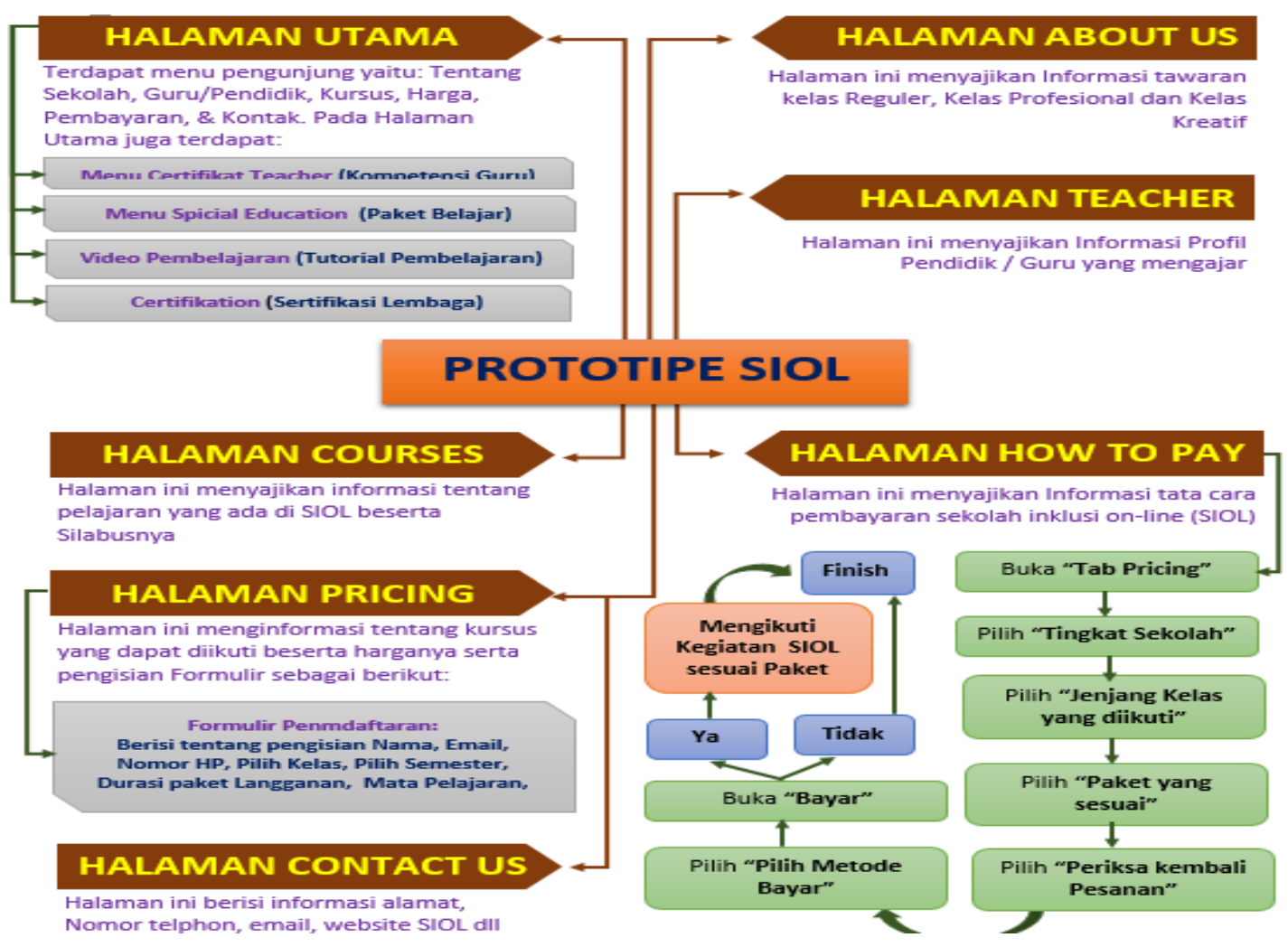

\footnotetext{
${ }^{13}$ Sulthon, S. (2019). Pendidikan Dasar Inklusif di Kabupaten Pati: Harapan dan Kenyataan. Inklusi, 6 (1), 151. https://doi.org/10.14421/ijds.060107
} 
Gambar 1.5

Aplikasi Sekolah Inklusi berbasis on-line
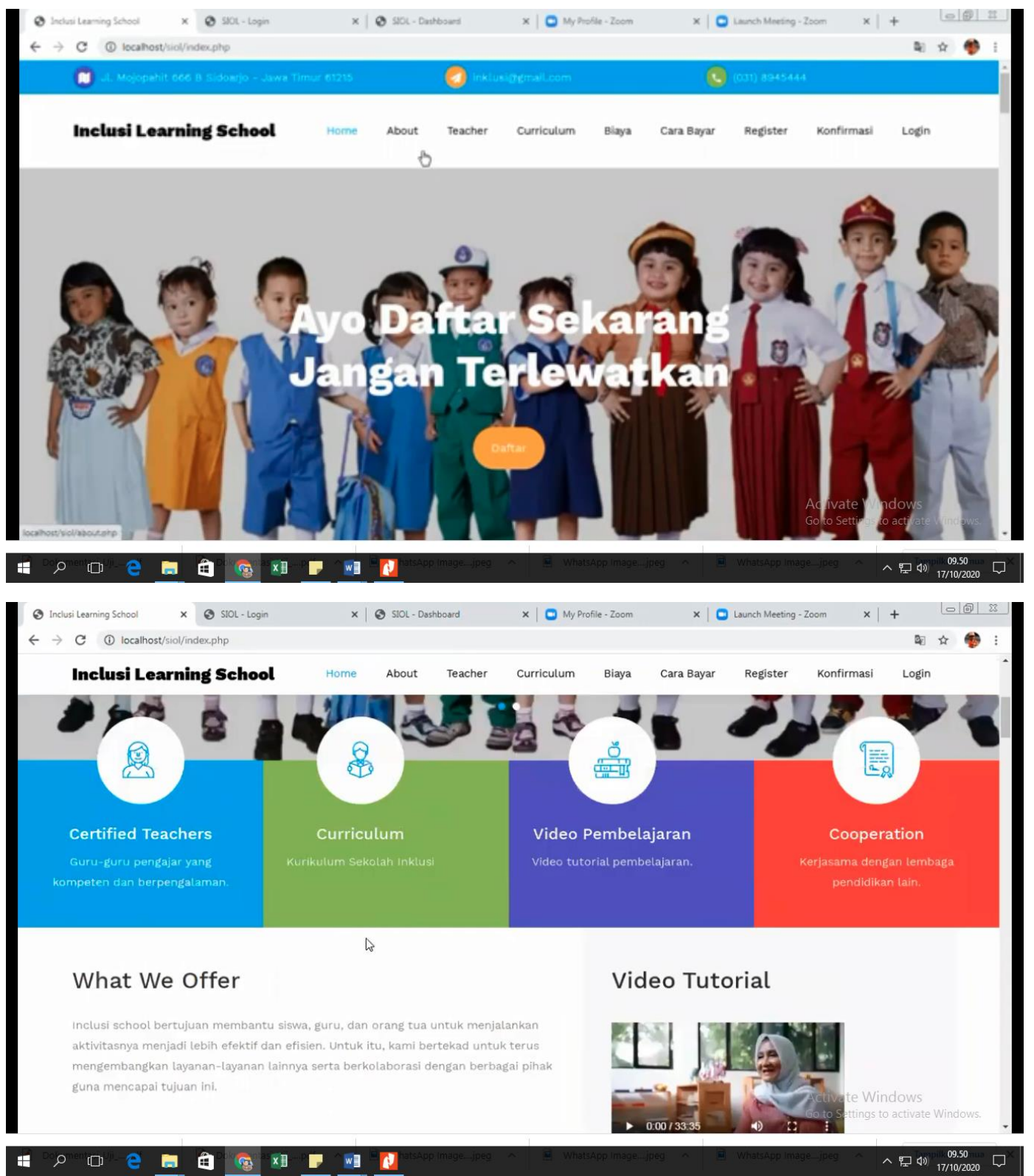

Para akhli pendidikan sepakat bahwa salah satu pijakan dalam penyusunan program hendaknya bertitik tolak dari kebutuhan anak, karena anak yang akan dibelajarkan. Untuk itu, masalah kebutuhan, perkembangan dan minat anak menjadi orientasi dalam mempertimbangkan penyusunan program modivikasi kurikulum berbasis on-line ini ditambah dengan kondisi pandemic covid 19 yang sampai saat ini masih belum reda sepenuhnya.

Dengan adanya modivikasi kurikulum yang nantikan akan diintegrasikan dengan sekolah inklusi on-line akan memberikan dampak yang sangat besar dalam membantu dan memfasilitasi anak inklusi untuk mendapatkan pembelajaran yang berkualitras sehingga permasalahan anak inklusi seperti perkembangan mental yang lambat, kesulitan belajar, berkomunikasi dan bersosialisasi dapat diminimalisir. 


\section{Kesimpulan}

Pengembangan dan modivikasi kurikulum yang dilakukan dalam rangka pelaksanaan sekolah inklusi berbasis aplikasi on-line berbeda dengan sekolah reguler. Modifikasi yang dilakukan dengan jalan perubahan bentuk soal, perincian dan pengembangan bahan ajar, detail penilaian berbasis penilaian individu dan pengayaanya berbasis capaian kemampuan siswa.

\section{Referensi}

Asrori. Psikologi Pendidikan: Pendekatan Multidisipliner. Purwokerto: Pena Persada, 2020.

Cooc, N. Teaching students with special needs: International trends in school capacity and the need for teacher professional development. Teaching and Teacher Education, 83, 27-41. 2019 https://doi.org/10.1016/j.tate.2019.03.021

Darma, I. P., \& Rusyidi, B. Pelaksanaan Sekolah Inklusi Di Indonesia. Prosiding Penelitian Dan Pengabdian Kepada Masyarakat, 2(2), 2015

Dinas Pendidikan \&Kebudayaan Kab. Sidoarjo. (2019). Data lembaga Inklusi Se Kabupaten Sidoarjo tahun 2018. Sidoarjo. 2019

Direktorat Pembinaan Sekolah Luar Biasa. Pedoman Khusus Penyelenggaraan Pendidikan Inklusid, Manajemen Sekolah Penyelenggara Pendidikan Inklusif. Jakaarta. 2007

Farrel, M.. Understanding special educational needs, a guide for student teachers. London: Routledge Falmer. 2003

Kristiawati, W. dan R. Gambaran sekolah inklusif di Indonesia: Tinjauan sekolah menengah pertama [The overview of inclusive school in Indonesia: Reviews of Junior High Schools]. Gambaran Sekolah Inklusif Di Indonesia Tinjauan Sekolah Menengah Pertama. 2016

Lincoln, N. K. D. dan Y. S. Handbook of Qualitative Research. Terj. Dariyatno dkk. Jogjakarta: Pustaka Pelajar. 2009

Mulyasa. Pengembangan dan Implementasi Kurikulum 2013. Bandung: Remaja Rosda Karya. 2015

Mapunda, P. H., Omollo, A. D., \& Bali, T. A. L. Challenges in identifying and serving students with special needs in Dodoma, Tanzania. International Journal of Child Care and Education Policy, 11(1). 2017 https://doi.org/10.1186/s40723017-0036-8

Nasution, S. Pengembangan Kurikulum. Bandung: Citra Aditya Bakti. 2012

Sulthon, S. Pendidikan Dasar Inklusif di Kabupaten Pati: Harapan dan Kenyataan. Inklusi, 6(1), 151. 2019 https://doi.org/10.14421/ijds.060107

https://doi.org/10.24198/jppm.v2i2.13530 